\title{
Efektivitas Bantuan Produktif Usaha Mikro Di Masa Pandemi Covid-19 Pada Dinas Koperasi Dan Usaha Kecil Menengah Kabupaten Bener Meriah Tahun 2020
}

\author{
Selaku Wali Putra, Muhammad Abubakar, Rusydi Abubakar \\ Prodi Magister Administrasi Publik, Fakultas Ilmu Sosial dan Ilmu Politik Universitas Malikussaleh \\ Jln. Tengku Chik diTiro, NO. 26, Lancang Garam, Lhokseumawe-24351 \\ Korespondensi: e-mail: mabubakar@unimal ac.id
}

\begin{abstract}
Penelitian ini mengkaji tentang efektivitas program bantuan Presiden produktif usaha mikro di masa pandemi Covid-19. Penelitian dilakukan di Dinas Koperasi dan UKM Kabupaten Bener Meriah dimana ditemukan fenomena yaitu belum efektif dan tepat sasarannya pelaksanaan program BPUM pada tahun 2020. Tujuan penelitian adalah untuk menganalisis efektivitas implementasi program BPUM dan hambatan dalam implementasinya. Perspektif teoritik yang digunakan adalah teori efektivitas implementasi program menurut Kertonogoro dengan 4 indikator yaitu komunikasi, sumber-sumber, kecendrungankecendrungan atau tingkah laku, dan struktur birokrasi. Metode Penelitian yang digunakan adalah metode penelitian kualitatif melalui teknik pengumpulan data observasi, wawancara dan dokumentasi. Hasil penelitian menunjukkan bahwa pada tahun 2020 telah diberikan 7.160 BPUM kepada pemilik UMKM di Bener Meriah, dengan total anggaran yang diterima sebesar Rp 17.184.000.000,-. Komunikasi dilakukan melalui sosialisasi informasi menggunakan surat edaran dan media massa radio. Sumber daya manusia dan sumber daya finansial menjadi permasalahan paling siginifikan dalam menjadikan implementasi BPUM belum efektif karena Dinas Koperasi dan UKM hanya memiliki 3 orang staf yang bertugas menginput 11.053 data calon penerima UMKM dan keterbatasan anggaran dinas menjadikan tidak adanya penambahan pegawai operator. Dinas Koperasi dan UKM sudah komit untuk menerapkan program BPUM namun ada oknum-oknum yang mengatasnamakan dinas yang melakukan indikasi percaloan dalam masa pengumpulan data calon penerima BPUM dengan menawarkan janji-janji dan berharap imbalan. Struktur birokrasi tanpa sengaja dipersempit karena keterkaitannya dengan terbatasnya SDM dan sumber daya finansial dan hanya membatasi pelaksanaan dilakukan oleh 3 orang staf bagian UKM

Keywords: BPUM, Pandemi Covid-19, Usaha Mikro.
\end{abstract}

\section{Pendahuluan}

Pandemi covid-19 yang terjadi saat ini mau tidak mau memberikan dampak terhadap berbagai sektor. Pada tataran ekonomi global, pandemi covid-19 memberikan dampak yang sangat signifikan pada perekonomian domestik negara-bangsa dan keberadaan Usaha Mikro, Kecil, dan Menengah (UMKM).Kajian yang dibuat oleh Kementerian Keuangan menunjukkan bahwa pandemi covid-19 memberikan implikasi negatif bagi perekonomian domestik seperti penurunan konsumsi dan daya beli masyarakat, penurunan kinerja perusahaan, ancaman pada sektor perbankan dan keuangan, serta eksistensi UMKM.

Terkait bantuan kepada UMKM, dua lembaga pemerintah yang berurusan langsung dengan UMKM yakni Kementerian Koperasi dan Usaha Kecil Menengah (KemenkopUKM) dan Kementerian Perindustrian (Kemenperin) telah merancang beberapa strategi untuk membantu UMKM. KemenkopUKM telah memberikan setidaknya tiga stimulus bagi UMKM di masa pandemi ini guna menjaga keberlangsungan aktivitas UMKM, yakni: kelonggaran pembayaran pinjaman, keringanan pajak UMKM enam bulan, dan transfer tunai untuk bisnis skala mikro.

Fenomena permasalahan krisisnya kondisi UMKM seluruh daerah menjadikan Presiden 
melalui Kementerian Koperasi dan Usaha Kecil Menengah mengeluarkan kebijakan berupa pemberian bantuan produktif usaha mikro di masa pandemicovid-19 yang diperuntukkan kepada para pengusaha mikro yang usahanya terdampak krisis akibat pandemi.

Berdasarkan Petunjuk Pelaksanaan Bantuan Bagi Pelaku Usaha Mikro (BPUM) Nomor 98 Tahun 2020 diketahui bahwa dalam rangka realisasi anggaran semua Program Pemulihan Ekonomi Nasional (PEN) dam mengambil langkah-langkah yang tidak biasa dengan tetap memperhatikan tata kelola yang baik dalam rangka percepatan program pemulihan ekonomi, Presiden menyiapkan Bantuan bagi Pelaku Usaha Mikro (BPUM) dengan tujuan untuk membantu usaha mikro agar mampu bertahan dalam menjalankan usaha di tengah krisis akibat pandemi covid-19. BPUM diberikan pemerintah melalui Kementerian Koperasi dan Usaha Kecil dan Menengah yang bersumber dari Anggarn Pendapatan dan Belanja Negara (APBN).

Sebagaimana diketahui untuk mendapatkan BPUM para pemilik usaha harus memiliki kriteria Warga Negara, memiliki Nomor Induk Kependudukan, memiliki usaha mikro yang dibuktikan dengan surat usulan calon penerima BPUM dari pengusul BPUM, Bukan Aparatur Sipil Negara, Anggota TNI, Anggota POLRI, Pegawai BUMN ataupun BUMD, tidak memiliki saldo di rekening Bank sebesar Rp 2.000.000,- dan tidak terdaftar sebagai nasabah yang memiliki kredit di Bank. Para pemilik usaha yang sudah memenuhi kriteria tersebut kemudian mengusulkan kelengkapan berkas berupa KTP, Kartu Keluarga, Foto usaha, dan Surat Keterangan Usaha dari Kepala Desa.

Berdasarkan hasil observasi awal peneliti diketahui di Kabupaten Bener Meriah terdapat 3.317 UMKM yang terdata di Dinas Koperasi dan Usaha Kecil Menengah Kabupaten Bener Meriah per 31 Desember 2019 sebelum adanya informasi pemberian Bantuan Produktif Usaha Mikro (BPUM) dari pemerintah. Sementara setelah adanya informasi Presiden memberikan BPUM untuk setiap pelaku UMKM di seluruh kabupaten/kota, terjadi lonjakan terbentuknya UMKM di Kabupaten Bener Meriah yang mengajukan BPUM sebanyak 11.053 UMKM.

Terjadi kenaikan signifikan UMKM di Kabupaten Bener Meriah pada setiap Kecamatannya.Para pelaku UMKM mulai mendaftarkan usahanya untuk mendapatkan BPUM sebagai bentuk bantuan masa sulit ditengah pandemi covid-19 untuk meningkatkan perekonomian masyarakat.

Berdasarkan data awal yang peneliti peroleh, Dinas Koperasi dan UKM Kabupaten Bener Meriah mengajukan 11.053 UMKM untuk program BPUM dan yang disetujui untuk diberikan bantuan oleh Kementrian Koperasi dan Usaha Kecil Menengah adalah sebanyak 7.160 UMKM dengan total anggaran yang diterima sebesar Rp 17.184.000.000,- sehingga masing-masing UMKM mendapatkan $\mathrm{Rp} 2.400 .000$,- dari program BPUM tersebut.

Permasalahan yang terjadi di Kabupaten Bener Meriah Tahun 2020 terkait dengan bantuan presiden produktif usaha mikro adalah pembagian bantuan yang tidak merata dan belum tepat sasaran, banyak pihak-pihak lain yang selama ini tidak memiliki usaha mikro mendadak menjadi memiliki usaha dan ikut mengajukan bantuan presiden usaha mikro dan lolos sebagai penerima bantuan tersebut, sementara para pemilik UMKM yang memang memiliki usaha sejak lama dan ikut mengajukan BPUM tidak mendapatkan bantuan tersebut.Berdasarkan fenomena masalah tersebut peneliti tertarik untuk meneliti topik permasalahan terkait dengan efektivitas bantuan presiden produktif usaha mikro pada Dinas Koperasi dan Usaha Kecil Menengah Kabupaten Bener Meriah Tahun 2020.

\section{Rumusan Masalah}

1. Apakah Dinas Koperasi dan UKM sudah efektif dalam menerapkan program Bantuan Presiden Produktif Usaha Mikro di Kabupaten Bener Meriah?

2. Apasaja hambatan Dinas Koperasi dan UKM dalam menerapkan program Bantuan Presiden Produktif Usaha Mikro kepada para pemilik UMKM di Kabupaten Bener Meriah pada tahun $2020 ?$

\section{Kajian Terdahulu: Landasan Teoritis}


Teori merupakan landasan yang teramat penting dalam memahami, menafsirkan dan memaknai data, oleh karena itu untuk memudahkan penafsira data dalam penelitian ini, maka penulis menggunakan beberapa teori sebagai berikut:

\section{Efektivitas Implementasi Program}

Program merupakan unsur pertama yang harus ada demi tercapainya kegiatan implementasi. Unsur kedua yang harus di penuhi dalam proses implementasi program yaitu adanya kelompok masyarakat yang menjadi sasaran program, sehingga masyarakat dilibatkan dan membawa hasil dari program yang dijalankan dan adanya perubahan dan peningkatan dalam kehidupannya. Tanpa memberikan manfaat kepada masyarakat maka dikatakan program tersebut telah gagal dilaksnakan. Berhasil atau tidaknya suatu program di implementasikan tergantung dari unsur pelaksanaannya (eksekutif).Unsur pelaksanaan ini merupakan unsur ketiga. Pelaksanaan penting artinya karena pelaksanaan baik itu organisasi maupun perorangan bertanggunujawab dalam pengelolaan maupun pengawasan dalam proses implementasi. (Riggs, 2005:54).

Dari uraian diatas dapat disimpulkan bahwa implementasi program ádalah tindakan-tindakan yang dilaksanakan oleh individu-individu atau pejabat-pejabat terhadap suatu objek atau sasaran yang diarahkan untuk mencapai tujuan-tujuan yang telah ditetapkan sebelumnya, melalui adanya organisasi, interpretasi dan penerapan.

Gunakan mencapai tujuan impementasi program secara efektif, pemerintah harus melakukan aksi atau tindakan yang berupa penghimpunan sumber dana dan pengelolaan sumber daya alam dan manusia. Hasil yang diperoleh dari aksi pertama dapat disebut input kebijakan, sementara aksi yangkedua disebut sebagai proses implementasi kebijakan (Ratmiko, 2005:4). Untuk mengoperasionalkan implementasi program agar tercapainya suatu tujuan serta terpenuhinya misi program diperlukan kemampuan yang tinggi pada organisasi pelaksanaannya.

Model efektifitas implementasi program yang ditawarkan oleh Kertonegoro (2004 : 17) terbagi menjadi 4 indikator dalam melaksansakan suatu kebijakan, diantaranya:

1. komunikasi,

2. sumber-sumber,

3. kecenderungan-kecenderungan atau tingkah laku

4. struktur birokrasi.

Berdasarkan indikator diatas yaitu komunikasi, sumber-sumber, kecendrungan-kecendrungan atau tingkah laku, dan struktur birokrasi merupakan hal penting dalam efektif atau tidak efektifnya yang mempengaruhi implementasi sebuah program.indikator-indikatortersebut akan menghasilkan kinerja dan dampak suatu program yaitu sejauh mana suatu program dapat mencapai sasaran yang telah ditetapkan, mengetahui bagaimana perubahan kemampuan administratif pada organisasi lokal serta berbagai keluaran dan hasil yang lain.

\section{Kebijakan Publik}

Kebijakan publik merupakan suatu ilmu multidisipliner karena melibatkan banyak disiplin ilmu seperti ilmu politik, sosial, ekonomi, dan psikologi. Menurut Dye dalam Nugroho (2008: 185) yang menyatakan bahwa kebijakan publik merupakan "segala sesuatu yang dilakukan dan tidak dilakukan oleh pemerintah".

Menurut Anderson dalam Subarsono (2005: 2), kebijakan publik merupakan "kebijakan yang ditetapkan oleh badan-badan dan aparat pemerintah". senada dengan hal ini Easton dalam Subarsono (2005: 2) mendefinisikan kebijakan publik sebagai "pengalokasian nilai-nilai kepada masyarakat", karena setiap kebijakan mengandung seperangkat nilai di dalamnya. Dari dua definisi ini dapat disimpulkan bahwa kebijakan publik juga menyentuh nilai - nilai yang ada dalam masyarakat.

Kebijakan dapat dikatakan keputusan atas sejumlah atau serangkaian pilihan yang berhubungan satu sama lain yang dimaksudkan untuk mencapai tujuan. Adapun lingkungan kebijakan adalah keadaan yang melatar belakangi atau peristiwa yang menyebabkan timbulnya sesuatu "isu" (masalah) kebijakan, yang mempengaruhi dan dipengaruhi oleh para pelaku kebijakan dan oleh kebijakan itu sendiri (Tachan, 2008: 19).

Menurut Tachan (2008: 15) kebijakan publik merupakan rangkaian keputusan yang 
mengandung konsekuensi moral yang didalamnya terdapat keterkaitan akan kepentingan rakyat banyak dan keterikatan terhadap tanah air atau tempat dimana yang bersangkutan berada.

Jamies dalam Solichin (2001: 42) mengatakan bahwa "kebijakan mencakup perumusan sebagai perihal/perbuatan dari sejumlah aktor (pejabat, kelompok, instasi pemerintah) termasuk perbuatan serangkaian aktor dalam suatu bidang kegiatan tertentu".

\section{Implementasi Program}

Mazmanian dan Sebastiar juga mendefinisikan implementasi sebagai berikut: Implementasi adalah pelaksanaan keputusan kebijakan dasar, biasanya dalam bentuk undang-undang, namun dapat pula berbentuk perintah-perintah atau keputusan-keputusan eksekutif yang penting atau keputusan badan peradilan.(Mazmanian dan Sebastiar dalam Wahab, 2004:68)

Implementasi menurut Mazmanian dan Sebastier merupakan pelaksanaan kebijakan dasar berbentuk undang-undang juga berbentuk perintah atau keputusan-keputusan yang penting atau seperti keputusan badan peradilan. Proses implementasi ini berlangsung setelah melalui sejumlah tahapan tertentu seperti tahapan pengesahan undang-undang, kemudian output kebijakan dalam bentuk pelaksanaan keputusan dan seterusnya sampai perbaikan kebijakan yang bersangkutan.

Program merupakan tahap-tahap dalam penyelesaian rangkaian kegiatan yang berisi langkahlangkah yang akan dikerjakan untuk mencapai tujuan dan merupakan unsur pertama yang harus ada demi tercapainya kegiatan implementasi. Program akan menunjang implementasi, karena dalam program telah dimuat berbagai aspek antara lain :

1. Adanya tujuan yang ingin dicapai.

2. Adanya kebijaksanaan-kebijaksanaan yang diambil dalam mencapai tujuan itu.

3. Adanya aturan-aturan yang harus dipegang dan prosedur yang harus dilalui.

4. Adanya perkiraan anggaran yang dibutuhkan.

5. Adanya strategi dalam pelaksanaan (Manila, $2006: 43$ ).

Selanjutnya Keban (2004 : 35), menyebutkan : Apakah program efektif atau tidak, maka stándar penilaian yang dapat dipakai adalah organisasi, interpretasi, penerapan.Ketiga standar penilaian tersebut dapat dijelaskan sebagai berikut:

1. Organisasi

Maksudnya disini ialah organisasi pelaksanaan program.Selanjutnya organisasi tersebut harus memiliki strukutur organisasi, adanya sumber daya manusia yang berkualitas sebagai tenaga pelaksana dan perlengkapan atau alatalat kerja serta didukung dengan perangkat hukum yang jelas. Stuktur organisasi yang kompleks,stuiktur ditetapkan sejak semula dengan desain dari berbagai komponen atau subsistem yang ada tersebut.

Sumber daya manusia yang berkualitas berkaitan dengan kemampuan aparatur dalam melaksanakan tugas-tugasnya.Aparatur dalam hal ini petugas yang terlibat dalam pelaksanaan program.Tugas aparat pelaksana program yang utama adlah memberikan pelayanan kepada masyarakat yang dipercayakan kepadanya untuk mencapai tujuan negara.Agar tugas-tugas pelaksana program dapat dilaksanakan secara efektif maka setiap aparatur dituntut memiliki kemampuan yang memadai sesuai dengan bidang tugasnya.

\section{Interpretasi}

Maksudnya disini agar program dapat dilaksanakan sesuai dengan peraturan atau ketentuan yang berlaku, harus dilihat apakah pelaksanaannya telah sesuaia dengan petunjuk pelaksana dan petunjuk teknis yang dikeluarkan oleh pejabat yang berwewenang.

a. Sesuai Dengan Peraturan

Sesuai dengan peraturan berarti setiap pelaksanaan kebijaksanaan harus sesuai dengan peraturan yang berlaku baik Peraturan Tingkat Pusat, Propinsi, Kabupaten.

b. Sesuai Dengan Petunjuk Pelaksana

Sesuai dengan petunjuk pelaksana berarti pelaksanaan kebijaksanaan dari peraturan 
sudah dijabarkan cara pelaksanaannya pada kebijaksanaan yang bersifat administratif, sehingga memudahkan pelaksana dalam melakukan aktifitas pelaksanaan program.

c. Sesuai Petunjuk Teknis

Sesuai dengan petunjuk teknis berarti kebijaksanaan yang sudah dirumuskan dalam bentuk petunjuk pelaksana dirancang lagi secara teknis agar memudahkan dalam operasionalisasi program.Petunjuk teknis ini bersifat strategis lapangan agar dapat berjalan efisien dan efektif, rasional dan realistis.

\section{Penerapan}

Maksudnya disini peraturan/kebijakan berupa petunjuk pelaksana dan teknis telah berjalan sesuai dengan ketentuan, untuk dapat melihat ini harus dilengkapi dengan adanya prosedur kerja yang jelas, program kerja serta jadwal kegiatan yang disiplin.

a. Prosedur kerja yang jelas Prosedur kerja yang sudah ada harus memiliki prosedur kerja agar dalam paelaksanaannya tidak tejadi tumpang tindih, sehingga tidak bertentangan antara unit kegiatan yang terdapat di dalamnya.

b. Program kerja Program kerja harus sudah terprogram dan terencana dengan baik, sehingga tujuan program dapat irealisasikan dengan efektif

c. Jadwal kegiatan Program yang sudah ada harus dijadwalkan kapan dimulai dan diakhiri suatu program agar mudah dalam mengadakan evaluasi. Dalam hal ini yang diperlukan adanya tanggal pelaksanaan dan rampungnya sebuah program sudah ditentukan sebelumnya.

\section{Bantuan Sosial}

Dalam undang-undang tentang Kesejahteraan Sosial telah dijelaskan bahwa Pancasila dan Undang-Undang Dasar 1945 mengamanatkan negara memiliki tanggung jawab untuk melindungi seluruh bangsa Indonesia, memajukan kesejahteraan sosial dan melindungi masyarakat dari risiko sosial yang mungkin terjadi. Negara menggunakan Anggaran Pendapatan dan Belanja Negara (APBN) yang dialokasikan dengan tujuan spesifik untuk melakukan hal tersebut. Khusus untuk memajukan kesejahteraan sosial dan melindungi masyarakat dari risikososial, pemerintah memiliki satu pos yang dinamakan bantuan sosial didalam APBN.

Bantuan sosial sendiri merupakan pengeluaran berupa uang, barang, atau jasa yang diberikan oleh pemerintah pusat atau daerah kepada masyarakat untuk melindungi masyarakat dari kemungkinan terjadinya risiko sosial, meningkatkan kemampuan ekonomi, serta kesejahteraan masyarakat (Kementrian Keuangan 2015:1). Risiko sosial yang dimaksud adalah peristiwa atau masalah yang dapat menimbulkan potensi kerentanan sosial baik itu yang tanggung oleh perseorangan maupun kelompok masyarakat sebagai dampak dari krisis sosial, ekonomi, politik, fenomena atau bencana alam dimana jika tidak diberikan bantuan sosial akan semakin terpuruk dan tidak dapat hidup dalam kondisi yang wajar.

\section{Metodologi Penelitian}

Penelitian ini menggunakan penelitian kualitatif dengan pendekatan deskriptif analisis, karena persoalannya sangat komprehensif, mendalam dan sangat luas. Pengumpulan data dilakukan dengan observasi, wawancara dan dokumentasi.

\section{Hasil Penelitian}

Bantuan produktif usaha mikro yang diberikan oleh Presiden melalui Kementerian Koperasi dan Usaha Kecil Menengah dalam rangka pemulihan ekonomi nasional, nyatanya masih belum mencapai kata efektif dalam pelaksanaannya di Kabupaten Bener Meriah.

Sebagaimana diketahui pelaksanaan program BPUM di Dinas Koperasi dan UKM Kabupaten 
Bener Meriah belum efektif karena pembagian bantuan yang tidak merata dan belum tepat sasaran, banyak pihak-pihak lain yang selama ini tidak memiliki usaha mikro mendadak menjadi memiliki usaha dan ikut mengajukan bantuan presiden usaha mikro dan lolos sebagai penerima bantuan tersebut, sementara para pemilik UMKM yang memang memiliki usaha sejak lama dan ikut mengajukan BPUM tidak mendapatkan bantuan tersebut.

Program merupakan unsur pertama yang harus ada demi tercapainya kegiatan implementasi. Unsur kedua yang harus di penuhi dalam proses implementasi program yaitu adanya kelompok masyarakat yang menjadi sasaran program, sehingga masyarakat dilibatkan dan membawa hasil dari program yang dijalankan dan adanya perubahan dan peningkatan dalam kehidupannya.

Tanpa memberikan manfaat kepada masyarakat maka dikatakan program tersebut telah gagal dilaksnakan. Berhasil atau tidaknya suatu program di implementasikan tergantung dari unsur pelaksanaannya (eksekutif).Unsur pelaksanaan ini merupakan unsur ketiga. Pelaksanaan penting artinya karena pelaksanaan baik itu organisasi maupun perorangan bertanggungjawab dalam pengelolaan maupun pengawasan dalam proses implementasi. (Riggs, 2005:54).

Campbel J.P menyebutkan untuk mengukur efektivitas dapat pula menggunakan indikatorindikator sebagai berikut:

1. Keberhasilan Program, berdasarkan hasil penelitian diketahui bahwa program BPUM yang diselenggarakan oleh Dinas Koperasi dan Usaha Kecil Menengah Kabupaten Bener Meriah Tahun 2020masih belum efektif, karena BPUM belum mampu terbagi secara merata, dan adil kepada para pemilik UMKM, banyak UMKM yang telah lama berdiri tidak mendapatkan bantuan tersebut, sementara UMKM baru lolos sebagai penerima bantuan.

2. Keberhasilan Sasaran, berdasarkan hasil penelitian diketahui bahwa keberhasilan sasaran juga belum dapat dikatakan efektif, karena target dari pemberian BPUM belum tepat sasaran sebagaimana tujuan pemberian bantuan di masa pandemi untuk UMKM di Kabupaten Bener Meriah.

3. Kepuasan Terhadap Program, berdasarkan hasil penelitian diketahui bahwa masyarakat banyak yang belum puas terhadap program tersebut, karena menganggap pemberian bantuan tidak adil dan merata, walaupun pihak dinas sudah menjelaskan bahwa yang memverifikasi untuk kelolosan calon peneriman bantuan adalah pihak kementerian, bukan pihak dinas.

4. Tingkat Input dan Output, input dalam penelitian ini adalah program BPUM yang diberikan pemerintah untuk pemulihan ekonomi nasional kepada para pemilik UMKM disetiap provinsi/kabupaten/kota, sedangkan outputnya adalah para UMKM yang terdampak pandemi dan susah dalam perekonomian karena terbatasnya ruang gerak dalam masa pandemi covid19 dapat memulihkan ekonominya dan tetap dapat menjalankan usaha sebagaimana mestinya, namun input dan ouput masih belum dapat menghasilkan outcome berupa manfaat nyata bagi pemulihan ekonomi masyarakat di Kabupaten Bener Meriah khususnya para pemilik UMKM. Sebagaimana disampaikan oleh Hani Handoko bahwa efektivitas merupakan hubungan antara output dengan tujuan, semakin besar kontribusi (sumbangan) output terhadap pencapaian tujuan, maka semakin efektif organisasi, program atau kegiatan. Efektivitas berfokus pada outcome (hasil), program, atau kegiatan yang dinilai efektif apabila output yang dihasilkan dapat memenuhi tujuan yang diharapkan.

5. Pencapaian Tujuan Menyeluruh, secara pencapaian tujuan menyeluruh, program BPUM belum dapat dikatakan efektif karena tujuan sasaran dari pelaksanaan program BPUM ini belum menyentuh semua pemilik UMKM, walaupun semua tahapan verifikasi dan validasi dilakukan oleh pihak kementerian, sedangkan pihak dinas hanya pada tahapan penerimaan berkas dan pengiriman data kepada provinsi dan kementerian, namun tujuan untuk pemulihan ekonomi para pemilik UMKM belum dapat tercapai secara menyeluruh.

Untuk menganalisis permasalahan penelitian terkait efektivitas bantuan presiden produktif usaha mikro pada Dinas Koperasi dan Usaha Kecil Menengah Kabupaten Bener Meriah Tahun 2020 
peneliti menggunakan teori Kertonegoro (2004: 17) yang menyebutkan indikator efektivitas implementasi program diantaranyaKomunikasi, Sumber-Sumber, Kecendrungan-Kecendrungan Atau Tingkah Laku, dan Struktur Birokrasi.

Berdasarkan hasil penelitian diketahui bahwa indikator komunikasi, diketahui para pelaksana program yaitu Dinas Koperasi dan UKM Kabupaten Bener Meriah telah melakukan komunikasi dalam bentuk sosialisasi informasi menggunakan surat edaran dan media massa radio untuk menyebarkan informasi kepada para pemilik UMKM di Bener Meriah yang terdampak pandemi Covid-19 dan sesuai dengan kriteria-kriteria calon penerima BPUM sesuai aturan dari pemerintah.

Meskipun pelaksanaan program BPUM belum dapat dikatakan efektif, namun pada indikator komunikasi Dinas Koperasi dan UKM sudah berupaya untuk melakukan komunikasi yang efektif dan efisien serta tidak menjadi permasalahan yang signifikan dalam mencapai efektivitas pelaksanaan program BPUM.

Berdasarkan hasil penelitian diketahui indikator sumber-sumber menjadi masalah yang paling signifikan, hal tersebut disebabkan oleh keterbatasan sumber daya di Dinas Koperasi dan UKM Kabupaten Bener Meriahmenyebabkan belum efektifnya implementasi program BPUM di Kabupaten Bener Meriah. Belum efektifnya karena pada tahapan penginputan data calon penerima mencapai 11.053 UMKM yang menyerahkan berkas, sumber daya di bagian UKM pada Dinas Koperasi dan UKM Kabupaten Bener Meriahsangat terbatas ketersediaannya yaitu hanya 3 orang.Dan pada saat dibutuhkan penambahan pegawai khususnyauntuk menjadi operator membantu penginputan data, Dinas Koperasi dan UKM Kabupaten Bener Meriahtidak memiliki anggaran untuk penambahan pegawai tersebut.Sehingga dapat disimpulkan bahwa sumber-sumber diantaranya sumber daya manusia dan sumber daya finansial memiliki keterkaitan dalam penelitian efektivitas bantuan presiden produktif usaha mikro pada Dinas Koperasi dan Usaha Kecil Menengah Kabupaten Bener Meriah Tahun 2020.

Berdasarkan hasil penelitian diketahui bahwa Dinas Koperasi dan UKM Kabupaten Bener Meriah melalui bagian UKM memiliki kecendrungan sebagai implementator sudah berupaya maksimal dalam memberikan bantuan kepada pemilik UMKM mengikuti program BPUM dari pemerintah, dan pemberian BPUM semuanya di atur dalam Peraturan Menteri Koperasi, Usaha Kecil dan Menengah Republik Indonesia Nomor 6 Tahun 2020 Tentang Pedoman Umum Penyaluran Bantuan Pemerintah Bagi Pelaku Usaha Mikro Untuk Mendukung Pemulihan Ekonomi Nasional Dalam Rangka Menghadapi Ancaman Yang Membahayakan Perekonomian Nasional Serta Penyelamatan Ekonomi Nasional Pada Masa Pandemi Covid-19.

Kecendrungan mendukung pelaksanaan program BPUM ini menjadi belum efektif karena ada pihak-pihak yang mengatasnamakan Dinas Koperasi dan UKM Kabupaten Bener Meriah menawarkan kepada para calon penerima BPUM bahwa mereka bisa meloloskan berkas pengajuan untuk mendapatkan BPUM kepada para pemilik UMKM atau dapat dikatakan muncul calo-calo yang mengatasnamakan dinas.

Berdasarkan hasil penelitian diketahui bahwa belum efektifnya program BPUM yang dilaksanakan oleh Pihak UKM Dinas Koperasi dan UKM Kabupaten Bener Meriah adalah pada saat staf bagian UKM Dinas Koperasi dan UKM Kabupaten Bener Meriah melakukan penginputan data dari berkas yang diajukan oleh pemilik UMKM. Terbatasnya ketersediaan staf dibidang UKM, sedangkan berkas yang masuk mencapai 11.053 UMKM, dan dengan sempitnya struktur birokrasi tersebut menjadikan penerapan BPUM menjadi belum efektif terutama mempengaruhi pemberian pelayanan kepada masyarakat pemilik UMKM.

Pihak Dinas Koperasi dan UKM Bener Meriah tidak bermaksud mempersempit struktur birokrasi para implementator yang menjalankan program BPUM namun keterbatasan sumber daya sebagaimana telah disampaikan pada indikator sumber-sumber yang menjadi penyebabnya.

Hambatan internal dari Dinas Koperasi dan UKM Bener Meriah adalah menyangkut dengan keterbatasan sumber daya manusia dan anggaran (sumber daya finansial) serta kedua faktor tersebut turut mempengaruhi pimpinan mengambil sikap secara tidak sengaja mempersempit struktur birokrasi para implementator yang menjalankan program BPUM yaitu hanya pada bagian UKM, dan memilih tidak menambah pegawai operator untuk membantu menginput 11.053 berkas calon penerima BPUM.

Hambatan eksternal yang menjadikan program BPUM belum efektif adalah adanya indikasi 
percaloan kepada para calon penerima BPUM dengan memberikan penawaran timbal balik jika para pemilik UMKM berhasil mendapatkan BPUM.Hal tersebut dilakukan oleh oknum-oknum yang mengatasnamakan Dinas Koperasi dan UKM Bener Meriah.

\section{Kesimpulan}

Berdasarakan hasil penelitian tersebut di atas, maka dapat disimpulkan sebagai berikut:

1. Bantuan Produktif Usaha Mikro (BPUM) merupakan salah satu bantuan untuk para pemilik UMKM se-Indonesia yang diberikan Presiden melalui Kementerian Koperasi dan UKM bagi para pemilik usaha mikro yang terdampak pandemi covid-19. Program BPUM di Kabupaten Bener Meriah pada tahun 2020 masih belum efektif diimplementasikan oleh Dinas Koperasi dan UKM, yang disebabkan oleh pembagian bantuan yang tidak merata dan belum tepat sasaran, banyak pihak-pihak lain yang selama ini tidak memiliki usaha mikro mendadak menjadi memiliki usaha dan ikut mengajukan bantuan presiden usaha mikro dan lolos sebagai penerima bantuan tersebut, sementara para pemilik UMKM yang memang memiliki usaha sejak lama dan ikut mengajukan BPUM tidak mendapatkan bantuan.

2. Hambatan internal dari dari Dinas Koperasi dan UKM Bener Meriah adalah menyangkut dengan keterbatasan sumber daya manusia dan anggaran (sumber daya finansial) serta kedua faktor tersebut turut mempengaruhi pimpinan mengambil sikap secara tidak sengaja mempersempit struktur birokrasi. Hambatan eksternal yang menjadikan program BPUM belum efektif adalah adanya indikasi percaloan kepada para calon penerima BPUM dengan memberikan penawaran timbal balik jika para pemilik UMKM berhasil mendapatkan BPUM

a. Kapasitas, kurangnya kemampuan kapasitas manusia dalam melaksanakan pemungutan pajak mineral bukan logam dan batuan sehingga mengakibatkan penerimaan terhadap pajak mineral bukan logam dan batuan terus mengalami penurunan di Kabupaten Bener Meriah dari tahun 2016-2020.

b. Karakter adalah watak implementor, pemugut pajak (fikus) dalam pelaksanaan pemungutan pajak mineral bukan logam dan batuan masih lemah, hal ini dikarenakan ketidakseriusan BPKPA dalam meningkatkan penerimaan pajak mineral bukan logam dan batuan, sehingga tidak terjadi peningkatan penerimaan yang maksimal seperti yang diharapkan.

c. Sistem Pemerintahan, pemungutan pajak mineral bukan logam dan batuan terus mengalami penurunan di Kabupaten Bener Meriah dari tahun 2016-2020, disebabkan dengan struktur birokrasi yang kurang jelas, terutama tidak sesuai dengan Peraturan Bupati Bener Meriah Nomor 20 tahun 2020 tentang Tata Cara Pengelolaan, Penetapan Tarif dan Pemungutan Pajak Mineral Bukan Logam dan Batuan oleh BPKPA Kabupaten Bener Meriah. 
Cambel. 1989. Riset dalam Evektivitas Organisasi, Terjemahan Salut Simamora. Jakarta: Erlangga. Kementerian Koperasi dan Usaha Kecil Menengah. "Perkembangan Data Usaha Mikro, Kecil, Menengah (UMKM) dan Usaha Besar (UB) Tahun 2017-2018

Kertonegoro, Sentanoe. 2004.Manajemen Organisasi. Jakarta: Widya Press.

Rachman, B. Agustian A, Wahyudi. 2018. Efektivitas Dan Perspektif Pelaksanaan Program Beras Sejahtera (RASTRA) Dan Bantuan Pangan Non-Tunai (BPNT).Analisis Kebijakan Pertanian, Volume 16 Nomor 1.

Santoso, Yusuf Imam. "Menghitung dampak Covid-19 terhadap dunia usaha hingga UMKM." Kontan.co.id.

Winarno, Budi. 2012. Kebijakan Publik: Teori, Proses Dan Studi Kasus. Yogyakarta: CAPS.

Keban,T. Yeremias. 2008. Enam Dimensi Strategis Administrasi Publik: Konsep, Teori dan Isu. Yogyakarta: Gava Media 